\title{
PHAL无NA LUNA.
}

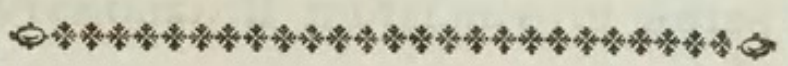

CH. RACTER GENERICUS.

Antennce fetaceæ, a bafi ad apicem fenfim attenuatæ.

Ala (fedentis) fæpius deflexæ. (Volatu nocturno.) Lin. Syft. Nat. p. 808.

CHARACTER SPECIFICUS, $\Xi^{\circ}$.

PHAL ENA alis viridi-pallentibus, inferioribus caudatis; omnibus ocello difci lunato.

PHALÆNA alis caudatis concoloribus virefcentibus; ocello difci lunato.

Lin. Syft. Nat. Gmel. p. 2404.

PHALRNA LUNA.

$$
\begin{aligned}
& \text { Lin. Syft. Nat. p. } 810 . \\
& \text { Cramer. 1. t. 2. A. \& 3. t. 31. A. B. } \\
& \text { Drury inf. 1. t. } 24 \text {. }
\end{aligned}
$$

Infolitæ eft pulchritudinis Phalæna Luna, alis omnibus pulcherrime viridi-pallentibus, fuperiorum margine antico fufco-purpureo. Alæ pofticæ excurrunt quafi in caudas. Alarum omnium mediam 
partem ornat macula hyalina, non abfimilis oculo. Generat phalænam Lunam America feptentrionalis, variæque partes provinciarum Britannicarum, nuperrime fœderatarum. 



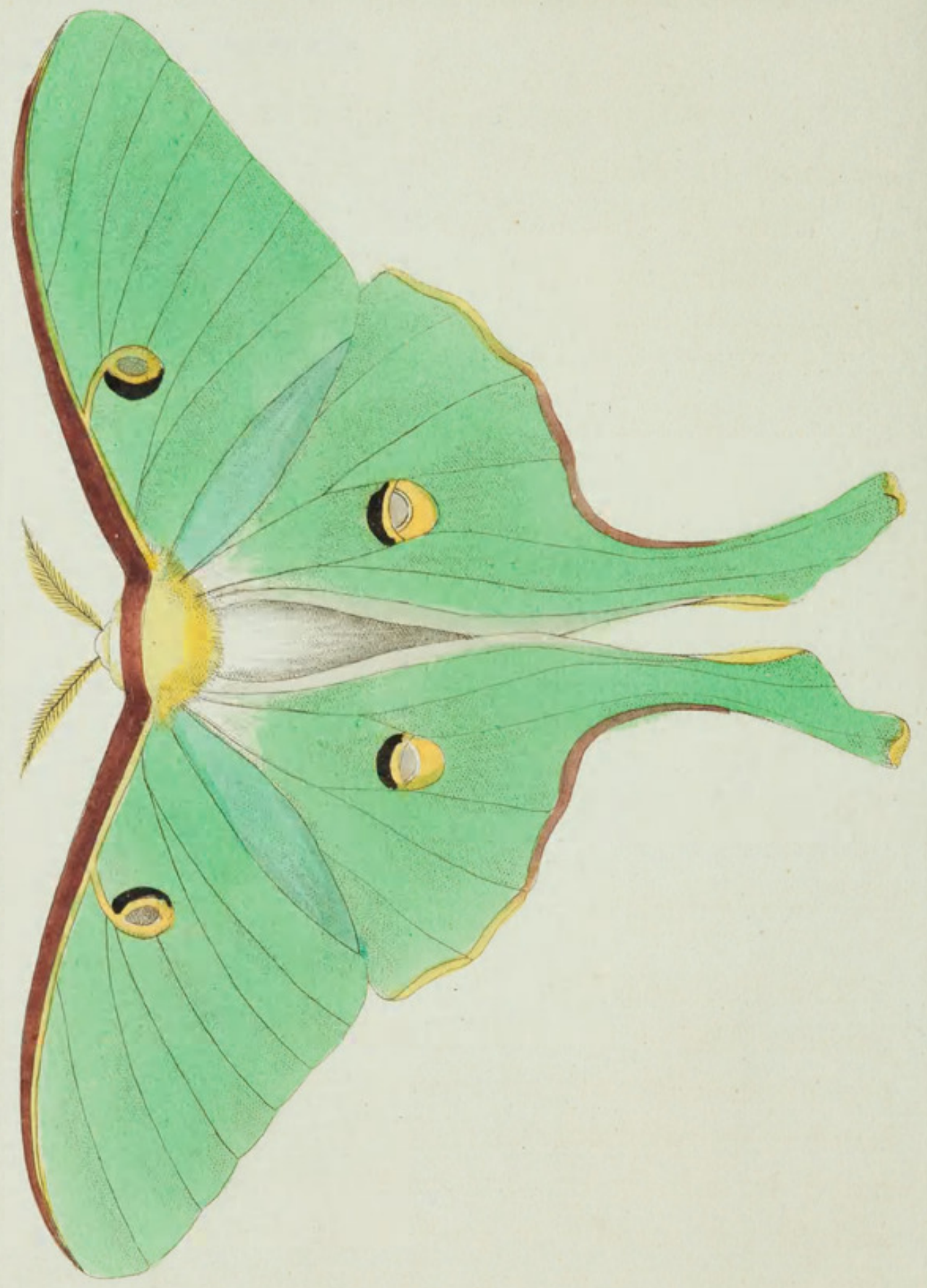




\section{U N A.}

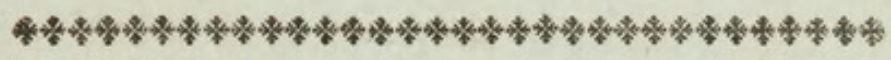

GENERIC CHARACTER.

Antennce or Horns fetaceous, decreafing in fize from the bafe to the point.

Wings, when at reft, generally deflected.

Fligbt mortly nocturnal.

SPECIFIC CHARACTER, Ec.

LARGE PEA-GREEN PHALÆNA, with the lower wings tailed, and a lunated tranfparent fpot on each wing.

The large caudated pea-green PHALÆNA.

The pea-green CAROLINA MOTH.

The Phalæna Luna is an infect of unufual elegance. The wings are of a beautiful pea-green; the upper edge of the fuperior pair marked by a band of purplifh-brown: the lower ones are terminated by a pair of lengthened proceffes or tails, and in the middle of each wing is a tranfparent fpot, refembling an eye. It is a native of North America, and is found in many parts of the United Britilh States. 


\section{$2 \mathrm{BHL}$ Biodiversity Heritage Library}

Shaw, George. 1796. "Luna, Phalæna luna [PI. 263]." The Naturalist's Miscellany 8(LXXXVIII), https://doi.org/10.5962/p.310806.

View This Item Online: https://www.biodiversitylibrary.org/item/276320

DOI: https://doi.org/10.5962/p.310806

Permalink: https://www.biodiversitylibrary.org/partpdf/310806

\section{Holding Institution}

Museums Victoria

\section{Sponsored by}

Atlas of Living Australia

\section{Copyright \& Reuse}

Copyright Status: Public domain. The BHL considers that this work is no longer under copyright protection.

This document was created from content at the Biodiversity Heritage Library, the world's largest open access digital library for biodiversity literature and archives. Visit BHL at https://www.biodiversitylibrary.org. 